\title{
CONCEPÇÕES DE ESCRITA EM PLANOS DE AULA DE ESTAGIÁRIOS DO CURSO DE LETRAS
}

\section{WRITING CONCEPTIONS IN LETTERS COURSE TRAINEE TEACHERS' CLASSES PLANNING}

\author{
Emanuelli Poletti ${ }^{1}$ \\ Cristiane Malinoski Pianaro Angelo ${ }^{2}$
}

Resumo: Neste artigo, discutimos as concepções de linguagem e de escrita que orientam a elaboração de propostas de produção textual escrita presentes em planos de aula de estagiários de um curso de Letras: Português. Os resultados apontam que, embora os documentos oficiais de ensino (BRASIL, 1998) e as pesquisas em Linguística Aplicada (MENEGASSI, 2010) defendam que a linguagem é um meio de interação e que a escrita é um trabalho, os planos analisados refletem as concepções de linguagem como expressão do pensamento e como instrumento de comunicação, as quais dão direções para se abordar a escrita em sala de aula como dom ou consequência.

Palavras-chave: concepções de linguagem; concepções de escrita; planos de aula; estagiários; curso de Letras.

Abstract: This work discusses language and writing conceptions which guide the preparation of proposals for written material presented in Portuguese Letters Course trainee teachers' classes planning. The results show that, despite regular teaching recommendations (BRASIL, 1998) and Applied Linguistics researches (MENEGASSI, 2010), which support that language is a means for interaction and that writing is a labour, the plans under analysis reflected conceptions of language as expressions of reasoning and communication tools that suggest an approach for class writing based on gift or consequence.

Key words: language conceptions; writing conceptions; classes planning; trainee teachers; Letters Course

\section{Concepções de linguagem e suas implicações no ensino da língua materna}

A maneira como a escola concebe a linguagem determina os procedimentos didático-pedagógicos no trabalho com a produção escrita em sala de aula. Por isso, iniciamos a discussão proposta neste artigo, revisando as três concepções de linguagem

\footnotetext{
${ }^{1}$ Graduanda do curso de Letras: Português. Universidade Estadual do Centro-Oeste/ Campus de Irati. Email: emanuellipoletti@hotmail.com

2 Docente do Departamento de Letras, Universidade Estadual do Centro-Oeste/ Campus de Irati. Doutoranda em Letras pela Universidade Estadual de Maringá. E-mail: malinoskicristiane@uol.com.br
} 
que têm orientado o processo de ensino e de aprendizagem da língua materna: a) a linguagem como expressão do pensamento; b) a linguagem como instrumento de comunicação; c) a linguagem como forma de interação (GERALDI, 1999; TRAVAGLIA, 2000; PERFEITO, 2005).

A concepção de linguagem como expressão de pensamento indica que a expressão se constrói na mente das pessoas e o que se exterioriza é apenas uma tradução do que está na mente. "E da capacidade de o homem organizar a lógica do pensamento dependerá a exteriorização do mesmo (do pensamento), por meio de linguagem articulada e organizada" (PERFEITO, 2005, p.28). Geraldi, refletindo a respeito dos pressupostos dessa concepção, acrescenta que "se concebemos a linguagem como tal, somos levados a afirmações - correntes - de que pessoas que não conseguem se expressar não pensam (1999, p.39).

Nessa perspectiva, o ensino da língua privilegia aspectos teórico-normativos, para que o aluno aprenda a organizar e a exteriorizar o pensamento adequadamente. Nas aulas de língua portuguesa, o eixo principal torna-se, então, a gramática com um fim em si mesmo, ou seja, os exercícios descontextualizados de concordância, colocação pronominal, regência, crase, ortografia, dentre outros. Conforme Penkal e Angelo:

\begin{abstract}
Ensinar língua, nessa concepção, é ensinar gramática - a gramática da norma culta - o que se traduz por ensinar a depreciar outras variedades lingüísticas, a disseminar preconceitos, a manter situações de exclusão, a reconhecer que existe uma variedade lingüística superior - aquela utilizada pela burguesia, pelos habitantes de núcleos urbanos, que são centros do poder econômico e do sistema cultural predominante (2008, p.183).
\end{abstract}

Ainda, a leitura e a escrita são vistas como práticas secundárias, como meios para que os alunos aprendam as regras do bem falar e do bem escrever. Assim, ler torna-se importante para que se perceba nos bons textos o emprego apropriado da norma culta e escrever consiste numa maneira "eficiente" de se treinar as regras gramaticais, transpondo-as adequadamente para o papel.

Na segunda concepção, a língua "é vista como um código, ou seja, um conjunto de signos que se combinam segundo regras e que é capaz de transmitir uma mensagem, informações de um emissor a um receptor" (TRAVAGLIA, 2000, p. 22). Desse modo, a linguagem é percebida como um meio de comunicação, objetivando, essencialmente, transmitir informações de um emissor (que produz a mensagem) a um receptor (que a recebe, passivamente). 
No esteio dessa concepção, as aulas de língua portuguesa ainda enfatizam o estudo da gramática, por meio de exercícios estruturais morfossintáticos (muitas vezes do tipo "siga o modelo"), para se buscar a internalização de hábitos linguísticos, próprios da norma culta (PERFEITO, 2005). Quanto à leitura, assim como na concepção anterior, não há a preocupação com a formação de leitores ativos e reflexivos, mas somente com "leitores" que decodifiquem a mensagem e extraiam as informações do texto. No que se refere à produção escrita, prioriza-se a estrutura do texto, restringindo-se o ensino de língua a uma abordagem superficial e descontextualizada. Para Perfeito:

com o objetivo de aumentar a fluência dos escritores, a prática de colocar as idéias no papel é antecedida de um reforço por parte do professor. Desse modo, comportamentos que aumentem a fluência do aluno são reforçados positivamente e vice-versa. Ainda a visão estrutural da frase transfere-se aos textos, analisados segundo a tipologia tradicional: narração, descrição e dissertação. E o período das técnicas de redação (2005, p.42).

Na terceira concepção, linguagem como forma de interação, "o que o indivíduo faz ao usar a língua não é tão-somente traduzir e exteriorizar um pensamento, ou transmitir informações a outrem, mas sim realizar ações, agir, atuar sobre o interlocutor (ouvinte/leitor)" (TRAVAGLIA, 2000, p.23). Desse modo, o objetivo das aulas de língua portuguesa consiste em propiciar ao aluno não apenas o reconhecimento da estrutura gramatical de sua língua, mas, principalmente, o aprimoramento das suas competências leitora e escritora e da capacidade de pensar criticamente a respeito do mundo que o cerca.

Penkal e Angelo, apoiando-se em Travaglia (2000), ressaltam que a concepção de linguagem como interação, refere-se, então, ao ensino produtivo:

que consiste em desenvolver habilidades/competências lingüísticas variadas para melhor fazer uso da língua e atuar em sociedade. Esse tipo de ensino não se prende a questiúnculas gramaticais e nem tenta liquidar a variedade lingüística de que o aluno dispõe, mas fornece subsídios - por meio de práticas de leitura, produção de texto e reflexão sobre os recursos lingüísticos - para que ele saiba adequar a linguagem conforme as circunstâncias sociais da interação social (2008, 182-183).

Para tanto, segundo as autoras, questiona-se a rotina tradicional, em que as atividades de leitura, produção e gramática são tratadas como blocos isolados, estanques, e defende-se um ensino em que as práticas de linguagem estejam inter- 
relacionadas de forma contextualizada, de modo a garantir ao aluno o domínio das habilidades de uso da língua em circunstâncias reais de interação.

Quanto ao trabalho com a leitura, na concepção interacionista, tem-se como objetivo a formação de um leitor crítico, o que, para Brandão e Micheletti, significa um sujeito que toma o texto não como uma fonte de verdades, mas com uma fonte de fatos e ideias que podem ser discutidos e confrontados com a realidade. Nas palavras das autoras, o leitor crítico:

- não é apenas um decifrador de sinais, um decodificador da palavra. Busca uma compreensão do texto, dialogando com ele, recriando sentidos implícitos nele, fazendo inferências, estabelecendo relações e mobilizando seus conhecimentos para dar coerência às possibilidades significativas do texto;

- é cooperativo, na medida em que deve ser capaz de construir o universo textual a partir das indicações que lhe são fornecidas;

- é produtivo, na medida em que, refazendo o percurso do autor, trabalha o texto e se constitui em um co-enunciador;

- é, enfim, sujeito do processo de ler e não objeto, receptáculo de informações (1997, p.21).

Em se tratando de produção textual, segundo Geraldi, as ações pedagógicas, numa ótica interacionista, buscam fazer com que o aluno-produtor de textos dialogue efetivamente com um interlocutor, tendo em vista uma finalidade concreta - condições que contornam a artificialidade e aproximam a escola da realidade social. As atividades de gramática, nessa perspectiva, passam a ser denominadas de práticas de análise linguística (GERALDI, 1999; BRASIL, 1998; PERFEITO, 2005). Essas ocorrem concomitantemente às atividades de leitura e produção e tem como objetivo fundamental ampliar o domínio das habilidades de uso da língua. Nesse sentido, a análise linguística não consiste numa nova denominação para o ensino de gramática; é, antes, um novo modo de conceber a língua e os objetivos do ensino.

\section{Concepções de escrita}

Podem-se constatar, na prática de produção de textos em sala de aula, várias perspectivas de escrita, as quais se encontram relacionadas com as diferentes concepções de linguagem e ensino em voga na escola. Menegassi (2010) aponta quatro concepções de escrita: a escrita com foco na língua, a escrita como dom ou inspiração, a escrita como consequência e a escrita como trabalho. 


\section{A escrita com foco na língua}

Esse modo de ver a escrita está atrelado à concepção de linguagem como expressão do pensamento (GERALDI, 1999; TRAVAGLIA, 2000; PERFEITO, 2005), a qual pressupõe o ensino de gramática tradicional como um fim em si mesmo. Dessa forma, quando se pensa a escrita de textos, nessa concepção, a preocupação maior volta-se aos aspectos normativos da língua: uso adequado da pontuação, ortografia, acentuação, emprego das regras de colocação pronominal, concordância nominal e verbal, dentre outros.

Alguns procedimentos comuns em sala de aula revelam uma postura que se coaduna com a concepção de escrita com foco na língua. Uma delas é quando o professor ou o livro didático aborda um tópico gramatical e, logo após, o aluno deve aplicar numa produção escrita os conhecimentos obtidos na explicação ou nos exercícios. Exemplo disso é a proposta de produção de texto presente em um livro didático de 6응 ano/5ํㅗ série do Ensino Fundamental. Antes da proposta há uma explicação a respeito de discurso direto e indireto e, em seguida, apresenta-se o seguinte comando:

Produza um texto imaginando um marimbondo e uma abelha que se encontram num mesmo jardim e começam a conversar. Crie um diálogo entre eles. Atenção para a pontuação! Empregue discurso direto e indireto em seu texto, colocando um título bastante expressivo (PARANÁ, 2005, p.92).

Evidencia-se, nesse exemplo, a concepção de escrita com foco na língua, determinando-se ao aluno a aplicação de tópicos de gramática estudados em sala de aula: emprego do discurso direto e indireto e o uso adequado da pontuação.

Outro procedimento comum em sala de aula, que se vincula a essa concepção, consiste na prática de correção de textos em que o professor deixa de lado os elementos das condições de produção (interlocutor, finalidade, lugar de circulação etc.) e mostra-se mais propenso em corrigir elementos normativos, assinalando no texto do aluno os erros cometidos por ele. Também nos livros didáticos, muitas vezes encontramos sugestões para a correção de textos que evidenciam esse mesmo ponto de vista a respeito da escrita. Por exemplo:

Após a leitura dos diferentes textos, escreva de forma organizada o que você ficou conhecendo sobre os quelônios.

Passe para um colega ler e fazer as devidas interferências quanto a:

- ortografia; 
- $\quad$ paragrafação;

- clareza das ideias;

- $\quad$ acentuação;

- fidelidade ao tema;

- relação entre os textos;

Ao receber seu texto, releia e busque resolver as situações apontadas pelo colega. Se precisar, busque a ajuda do colega ou do professor. (PARANÁ, 2005, p.45)

A reescrita de textos é parte do processo de produção textual. Portanto, deve ser sempre trabalhada em sala de aula. No entanto, verificamos que, nessas orientações, reescrever o texto é fazer "higienização", ou seja, eliminar problemas de ordem normativogramatical, demonstrando-se os vínculos da proposta com a concepção de escrita com foco na língua.

\section{A escrita como dom/inspiração divina}

Esse modo de ver a escrita também se encontra relacionado à concepção de linguagem como expressão do pensamento (GERALDI, 1999; TRAVAGLIA, 2000; PERFEITO, 2005). A produção textual surge de um título, ou de uma frase, que é exposta ao aluno para que ele escreva uma redação, sem antes ocorrerem atividades prévias para embasamento de informações, como leituras, pesquisas e discussões a respeito do tema, as quais podem auxiliar o aluno no trabalho de planejar e escrever o texto. Por exemplo:

"Escreva uma dissertação a respeito da importância de preservarmos a natureza".

Desse modo, "o aluno deverá buscar em seus conhecimentos e nas informações que conhece subsídios para escrever um texto; para isso, basta que tenha o 'dom divino' ou a 'inspiração divina' para produzi-lo” (MENEGASSI, 2010, p.77), resultando num texto artificial, sem finalidade e interlocutor definidos. Essas situações, quando corriqueiras nas aulas, acabam por desestimular o aluno pelo aprendizado da língua portuguesa, gerando produções escritas insatisfatórias.

\section{A escrita como consequência}

Atrelada à concepção de linguagem como meio de comunicação (GERALDI, 1999; TRAVAGLIA, 2000; PERFEITO, 2005), a escrita como consequência consiste no resultado de uma atividade realizada em classe ou extraclasse. Por exemplo, o aluno 
assiste a um filme e, logo em seguida, deve produzir um resenha; assiste a uma palestra e, após, deve fazer um resumo; realiza um passeio com a classe e, depois, precisa escrever um relatório, sem que haja um tempo para reflexão e amadurecimento das ideias. Nesses casos, "fica a impressão de que a penalidade por ter realizado uma atividade motivadora de interação, dentro ou fora da sala de aula, é a produção de um texto escrito" (MENEGASSI, 2010, p.77).

A experiência que presenciamos numa sala de aula do curso de Letras serve para ilustrar essa abordagem de escrita: a professora de uma determinada disciplina, ao perceber que suas aulas não estavam sendo muito atrativas, resolveu trabalhar um filme com os acadêmicos: o longa-metragem, "Duelo de Titans", que retrata jogos de futebol americano entre negros e brancos. Ao final do filme, a professora, sem estimular qualquer reflexão ou debate em sala de aula, pediu que os acadêmicos fizessem um relatório do filme, incluindo comentários a respeito do racismo e das diferenças sociais. Estabeleceu que o texto deveria ter pelo menos três páginas e deveria ser entregue no mesmo dia.

Nessa situação didática, o texto é visto como um registro escrito que serve para atribuição de nota e para comprovar que o aluno realizou a atividade proposta (MENEGASSI, 2010), uma vez que não houve exploração do filme de modo a possibilitar que os alunos constituíssem reflexões e posicionamentos.

\section{A escrita como trabalho}

Diferentemente das demais, essa abordagem vincula-se à concepção interacionista de linguagem. Dessa forma, escrever consiste numa atividade interativa e discursiva: "dizer alguma coisa a alguém, de uma determinada forma, num determinado contexto histórico e em determinadas circunstâncias de elocução" (BRASIL, 1998, p.20-21).

Segundo Geraldi (1993, p.137), uma prática textual condizente com a concepção interacionista precisa prever as seguintes condições: "a) se tenha o que dizer; b) se tenha uma razão para dizer o que se tem a dizer; c) se tenha para quem dizer o que se tem a dizer; d) o locutor se constitua como tal, como sujeito que diz o que diz e para quem diz; e) se escolham as estratégias (a), (b), (c) e (d)".

Tomemos, para discussão, uma proposta de produção de texto retirada de um livro didático de Língua Portuguesa - 4⿳亠丷a série/ $5^{\circ}$ ano do Ensino Fundamental: 
Observe dois exemplos de cartazes publicitários criados para a campanha de conscientização para o uso do cinto de segurança.

(no original são apresentados dois cartazes publicitários)

Para chamar a atenção do leitor, um dos recursos utilizados nos cartazes publicitários é a criação de enunciados que sugerem duplo sentido.

a) Quais os diferentes sentidos que as palavras amarre-se e vivo sugerem nos cartazes que você observou?

b) Observe e analise outros recursos utilizados:

* letras: tipo, forma e tamanho;

* presença ou não de desenhos;

* cores;

${ }^{*}$ forma sugerida pelo cartaz.

Agora, você e seus colegas vão colaborar com a campanha em prol do uso do cinto de segurança.

O QUE vocês vão criar? Cartazes publicitários

PARA QUEM? Para motoristas e passageiros.

PARA QUÊ? Para conscientizá-los de que o uso do cinto pode salvar-lhes a vida.

COMO? Escrevendo frases curtas, inteligentes e criativas para chamar a atenção dos leitores. Utilizando letras grandes (para facilitar a leitura à distância); desenhos (que ampliem o sentido da mensagem que vocês querem passar); cores (que se harmonizem suavemente ou que criem impacto); formas diferentes das tradicionais (em diagonal, triangular, circular etc.).

POR QUÊ? Utilizando a linguagem adequadamente, vocês vão alcançar o objetivo proposto - conscientizar e modificar comportamentos.

ONDE colocar os cartazes ou publicá-los? No pátio da escola, no jornal da escola ou de sua cidade.

(GOMES, S. Língua Portuguesa - 4aa série. São Paulo/SP: IBEP, 2001.p.97-98)

Constata-se que, na proposta do livro didático, os elementos das condições de produção estão claramente delimitados, o que caracteriza a escrita como um espaço de interação: explicitam-se os interlocutores (motoristas e passageiros); a finalidade (conscientizar motoristas e passageiros de que o uso do cinto pode salvar-lhes a vida); o gênero textual (cartazes publicitários); o local de circulação (no pátio da escola, no jornal da escola ou de cidade); as estratégias de produção (escrever frases curtas, inteligentes e criativas para chamar a atenção dos leitores; utilizar letras grandes (para facilitar a leitura à distância); desenhos (que ampliem o sentido da mensagem a ser passada); cores (que se harmonizem suavemente ou que criem impacto); formas diferentes das tradicionais (em diagonal, triangular, circular etc.). Além do mais, antes da comando de produção, há textos de apoio que, sendo bem explorados, debatidos em sala de aula, promovem uma 
ampliação do conhecimento do aluno a respeito da importância do uso cinto de segurança, contribuindo para que o aluno "tenha o que dizer".

Segundo Menegassi (2010), para que a escrita se constitua como trabalho, é preciso que sejam consideradas também as etapas de produção textual: o planejamento, a execução do texto escrito, a revisão e a reescrita. No planejamento, o aluno levará em conta as atividades prévias de leituras, debates e reflexões, bem como as condições de produção: finalidade, interlocutor, gênero, lugar de circulação - elementos que orientam a etapa da execução da escrita. Na etapa da revisão, realizada pelo próprio autor do texto, pelos pares e/ou pelo professor, o aluno observará se os elementos das condições de produção foram contemplados; se as informações foram suficientemente esclarecidas; se os aspectos relacionados à coesão e coerência foram considerados. Caso falte alguma dessas questões, o aluno reescreverá seu texto, tendo em vista o levantamento feito na revisão.

Embora as etapas da produção escrita sejam já bastante discutidas na literatura e os documentos oficiais tragam essa discussão, muitos livros didáticos de Língua Portuguesa desconsideram a natureza processual da escrita, como no último exemplo citado. Nesse, os elementos das condições de produção se fazem presentes, auxiliando o aluno na fase de planejamento e execução, no entanto não há orientações para a revisão e reescrita, etapas fundamentais para a constituição da escrita como trabalho.

\section{3) Uma análise das concepções de escrita em planos de aula de estagiários do curso de Letras:}

Realizamos, nesta seção, uma análise de propostas de produção de textos, para alunos de Ensino Médio, que constam em dois planos de aula elaborados, em 2011, por estagiários do $4^{\circ}$ ano do curso de Letras: Português, da Unicentro/ Campus de Irati ${ }^{3}$.

Partimos do pressuposto de que o plano de aula é uma ferramenta imprescindível para o fazer pedagógico em sala de aula. Por meio dele, o professor pode prever os conteúdos que serão trabalhados, as atividades que serão desenvolvidas, os procedimentos metodológicos que serão adotados, os objetivos a serem atingidos e as

\footnotetext{
${ }^{3}$ Os planos de aula que constam neste artigo, bem como o Plano de ensino de Estágio Supervisionado de Língua Portuguesa, foram cedidos pela professora que ministrava a disciplina no ano letivo de 2011.
} 
formas de avaliação que serão priorizadas. Segundo Grillo ${ }^{4}$, um plano de aula consiste em:

uma previsão de atividades vinculadas a um plano de ensino mais amplo desenvolvidas em etapas seqüenciais, em consonância com objetivos e conteúdos previstos. Serve para organizar a intenção do professor e o modo de operacionalizá-la. Expressa, ainda, as opções desse professor diante de seu contexto de trabalho, que implica pensar simultaneamente 0 conteúdo e os sujeitos com os quais interage.

$\mathrm{Na}$ disciplina de Língua Portuguesa, além de ser um instrumento orientador, o plano de aula traz implícito o modo como o professor pensa a linguagem, com repercussões diretas no como ensinar a leitura, a produção escrita e a gramática em sala de aula.

Nesse sentido, ao analisarmos os planos de aula nesse artigo, buscamos levantar que concepção ou concepções de linguagem e de escrita estão orientando as ações do estagiário em sala de aula, o que, também, revela as concepções que estão sendo construídas ou reafirmadas no decorrer da formação desses futuros professores.

Ressaltamos que a "elaboração dos planos de aula com os conteúdos a serem ministrados nas aulas de regência" é um dos itens que compõe o plano de ensino da disciplina de Estágio do curso de Letras: Português, no ano letivo de 2011. Nesse plano de ensino, consta ainda como um dos objetivos do Estágio "discutir as concepções vigentes do processo de ensino e de aprendizagem de Língua Portuguesa". O Programa da disciplina prevê a discussão das "Orientações oficiais para o ensino de Língua Portuguesa (ensino médio)": Diretrizes Curriculares de Língua Portuguesa do Estado do Paraná/ DCE's e Parâmetros Curriculares Nacionais de Língua Portuguesa/ PCN's. Na bibliografia básica e complementar do plano de ensino citam-se os documentos oficiais (DCE's, PCN's) e diversos artigos e livros, como, por exemplo:

- GERALDI, J. W. (org.). O texto na sala de aula. São Paulo: Ática, 1999.

- MENEGASSI, R. J. Leitura, escrita e gramática no ensino fundamental: das teorias às práticas docentes. Maringá: EDUEM, 2010.

- ANTUNES, I. Aula de Português: encontro e interação. São Paulo: Parábola Editorial, 2003.

\footnotetext{
${ }^{4}$ Jornal do Professor do Mec - Entrevista com a doutora em Educação, Marlene Grillo, professora titular do Programa de Pós-Graduação em Educação da Pontifícia Universidade Católica do Rio Grande do Sul (PUCRS) e assessora pedagógica da Pró-Reitoria de Graduação.
} 
- MENEGASSI, R. O processo de produção textual. In: SANTOS, A. R. dos; GRECO, E. A.; GUIMARÃES, T. B. (orgs.) A produção textual e o ensino. Maringá: Eduem, 2010. p.75-101.

- PERFEITO, A. M. Concepções de linguagem, teorias subjacentes e ensino de língua portuguesa. In: SANTOS, A. R. dos; RITTER, L. C. B. (org.). Concepções de linguagem e o ensino de língua portuguesa. UEM, 2005.

Em todos esses textos, defende-se que é a perspectiva interacionista que deve orientar o trabalho com a produção textos em sala de aula. Desse modo, as propostas de escrita, apresentadas nos planos de aula dos formandos do curso de Letras, deveriam ter claramente delimitados os elementos das condições de produção: interlocutor, finalidade, gênero textual, lugar de circulação, bem como evidenciar as etapas do processo de produção textual a ser desenvolvida em sala de aula: planejamento, execução, reescrita, condizendo com a concepção de escrita como trabalho.

\section{Plano de aula 1}

Data: 22/08/2011

Total de aulas: $3 \mathrm{~h} / \mathrm{a}$

Objetivo geral:

Propiciar a leitura, o debate e a produção de textos referentes à educação para o trânsito.

Objetivos específicos:

* Realizar leitura crítica de vídeo e frases sobre negligências no trânsito.

* Instigar discussões referentes ao tema "Educação para o trânsito" para favorecer a criticidade dos alunos.

* Propiciar condições para que os alunos produzam textos sobre a temática "Educação para o trânsito".

Procedimentos metodológicos:

1. Passarei um vídeo intitulado "O Certo e o Errado no trânsito".

2. Solicitarei para que os alunos escrevam no caderno, a partir do vídeo, alguns comportamentos certos e errados no trânsito.

3. Faremos a reflexão sobre o filme, a partir das respostas dadas pelos alunos.

4. Entregarei fotocópias de frases sobre o trânsito para possíveis discussões sobre o assunto, envolvendo o filme e as frases.

* "Não se esqueçam: quem vai com pressa demais deixa a vida para trás" (KLEITON E KLEDIR).

* "Queria chamar a atenção para aquela coisa de que jovem como nós gosta de fazer, que é correr de carro. Não é legal de brincar com isso, nem quando se está de cara limpa e, principalmente se você bebeu. Quando seu amigo pedir pra você ir mais devagar e você chama ele de babaca, lembre-se que babaca é quem morre com 18 anos num acidente de carro! Vamos se ligar que vida a gente tem uma só. Dá-se jeito em tudo mas depois de morto não tem mais jeito." (RODRIGO SANTORO)

* "Frente ao custo exorbitante do petróleo, não se discutem o atual modelo de transporte, baseado na definição de que a gente é um animal que caminha com duas pernas e quatro rodas (...). Debate-se como alimentar veículos, que somam 800 milhões em todo planeta-o mesmo 
número de bocas em situação de desnutrição crônica, agora agravada pelo aumento do preço dos alimentos." (FREI BETTO)

5. Entregarei, para leitura e discussão, um artigo de opinião a respeito da violência no trânsito (Anexo 1). Discutirei oralmente as seguintes questões:Quais as causas de violências no trânsito? Que medidas poderiam ser tomadas pelos condutores de veículos para evitar acidentes? Você concorda com as leis de trânsito? Acha que essas leis são fiscalizadas rigorosamente? Os meios de comunicação têm chamado a atenção para os cuidados com o trânsito?

6. Relembrarei com os alunos o conceito de dissertação e entregarei um modelo desse tipo de texto.

7. ENTREGAREI AOS ALUNOS A SEGUINTE PROPOSTA DE PRODUÇÃO DE TEXTO

"A PARTIR DAS DISCUSSÕES REALIZADAS EM SALA DE AULA, PRODUZA UM TEXTO DISSERTATIVO QUE ABORDE A TEMÁTICA "A IMPORTÂNCIA DO CIDADÃO COMPORTASE DE FORMA CONSCIENTE NO TRÂNSITO".

\section{Plano de aula 2}

Data: $23 / 08 / 2011$

Total de aulas: $2 \mathrm{~h} / \mathrm{a}$

Objetivos:

- Ampliar os conhecimentos dos alunos a respeito da tipologia narração;

- Possibilitar a identificação dos elementos da narrativa no gênero conto;

- Criar condições para que os alunos escrevam uma narração, a partir das discussões realizadas em sala.

Procedimentos metodológicos:

- Iniciar a aula perguntando o que os alunos lembram acerca dos aspectos da narração comentados na aula anterior.

- Em seguida, entregar características principais (esquema) da narração e discutir com os alunos;

- Entregar o texto Menino Precoce de Stanislaw Ponte Preta para leitura e discussão.

- Questões para serem discutidas oralmente envolvendo os elementos da narrativa:

1- Quem são os personagens do texto? Caracterize-as.

2- Qual é o espaço presente no texto?

3- Comente a respeito do tempo na narrativa.

4- Como podemos caracterizar o narrador no conto "Menino Precoce"?

5- Acerca do enredo:

5.1- Onde se situa a apresentação?

5.2- E o desenvolvimento?

5.3- E o clímax?

5.4- E o desfecho?

- Proposta de produção escrita:

"Devido às condições, adolescentes obesos podem possuir graves problemas emocionais, sofrerem de depressão e outros problemas ligados a condição física, sendo que muitos deles procuram, de todos os modos, livrar-se das humilhações que, por vezes, passam devido a sua obesidade. Talvez por conseqüência de tantos problemas no convício social, jovens com excesso de peso geralmente possuem menos amigos que os adolescentes magros de sua idade. Fatores genéticos, ambientais e psicológicos, entre outros, podem causar a obesidade".

Considere o fragmento em evidência como uma oportunidade para que você se recorde de algum fato envolvendo um adolescente obeso e, num texto narrativo, conte como era a vida 
desse jovem, destacando o seu relacionamento na escola, com colegas e professores, dentre outros, e sinalizando se ele encontrou algum meio de libertar-se do problema que o afligia.

OBSERVAÇÕES:

1) Escreva seu texto usando uma linguagem fluente, que respeite as normas gramaticais.

2) Número de linhas:17. Número máximo: 22

3) Lembre-se de que uma narração pressupõe a presença de alguns elementos (fato, local, personagens, tempo, foco narrativo...)

Ao observarmos os procedimentos metodológicos especificados no primeiro plano de aula, constatamos que são oferecidos aos alunos três textos de apoio relacionados com o tema proposto para a produção: o vídeo: "O certo e o errado no trânsito"; frases de personalidades brasileiras sobre trânsito; artigo de opinião sobre violência no trânsito. Menciona-se, também, que se pretende propiciar momentos de discussão a respeito do conteúdo dos textos e relembrar a tipologia solicitada - a dissertação. Esses aspectos permitiriam avaliar a proposta como positiva, pois há uma preocupação com o conteúdo e com a forma do texto, no entanto, não há como desconsiderar a superficialidade com que o trabalho de leitura e discussão é proposto, haja vista que são previstas três horas-aulas para todo o trabalho, desde as leituras até a produção textual. Nesse sentido, a proposta reflete a concepção de escrita como consequência, pois, como afirma Menegassi (2010),

não há consideração do tempo de sedimentação necessário para a internalização dos conhecimentos e das informações que o aluno recebeu (VYGOTSKY, 1998; SERCUNDES, 1997; MENEGASSI; OHUSCHI, 2008). $O$ texto deve ser escrito logo em seguida, entregue e avaliado com rapidez, para que uma nova atividade possa ser implementada em sala de aula (2010, p.78).

Isto é, não se prevê, no plano de aula um tempo necessário para reflexões, para confrontos das informações textuais com as experiências vividas, para amadurecimento das opiniões e consolidação das próprias ideias pelo aluno.

Quanto ao segundo plano de aula, constata-se que há um trabalho prévio em relação à tipologia textual, mas não em relação à temática do texto. Assim, a escrita é considerada como dom, visto que não existem relações entre o texto a ser elaborado e os textos prévios, de apoio. Esse procedimento é semelhante à metodologia tradicional em que se propunha o "tema livre", no qual ficava por conta do aluno o "doloroso" trabalho de planejamento e elaboração textual. Almeida (1995, p. 34) explica que a "colocação de um tema livre numa aula de redação vai, hoje, sendo vista mais como um propósito 
comodista do professor do que propriamente, como uma metodologia adequada de quem pretenda extrair do aluno um razoável desenvolvimento de ideias". Assim, expor um tema livre ou sugerir um tema sem qualquer trabalho prévio não auxilia o aluno a ter sucesso na escrita. Ninguém consegue produzir um bom texto sem ter conhecimento suficiente a respeito do assunto e, segundo Britto (1997), esse é o motivo principal da falta de êxito dos alunos da produção de redações, em que se exige que o aluno escreva de forma clara, coerente, crítica, sem propiciar-Ihes subsídios para isso.

Quanto ao comando de produção proposto, no primeiro plano, observa-se que os elementos das condições de produção não se fazem presentes: não há delimitação de finalidade para a escrita, de interlocutor, de um lugar de circulação. Especifica-se somente a tipologia tradicional de redação, a dissertação, e a temática a ser produzida: "a importância do cidadão comportar-se de forma consciente no trânsito". No segundo plano de aula, além de um fragmento que trata da questão da obesidade, o comando solicita uma tipologia, a narrativa, e define a temática: contar um fato relacionado à vida de um adolescente obeso, "destacando o seu relacionamento na escola, com colegas e professores, dentre outros, e sinalizando se ele encontrou algum meio de libertar-se do problema que o afligia". Aparecem ainda algumas orientações formais: escrever numa linguagem fluente, "que respeite as normas gramaticais"; número mínimo e máximo de linhas; elementos da narrativa (fato, local, personagens, tempo, foco narrativo...). De modo semelhante ao primeiro plano, este também não especifica uma finalidade, um interlocutor e um lugar de circulação.

Desse modo, as situações propostas perdem sua característica fundamental da escrita: o caráter interlocutório. O aluno escreve para o professor, somente, e com um único objetivo: executar uma tarefa que lhe foi imposta e obter nota. O que dizer e as estratégias do dizer são provenientes, no primeiro plano, da reprodução dos textos prévios, já que não há um tempo para reflexão e elaboração de ideias; e, no segundo, da inspiração, do "dom" de escrever. Consequentemente, há uma função-aluno, já que não existe comprometimento da palavra nem articulação de pontos de vistas. "É nesse sentido que o ensino se constrói como reconhecimento e reprodução" (GERALDI, 1993, p.158).

Nota-se, ainda, que em ambas as propostas, a elaboração do texto (em uma única versão) é o ponto final do processo de produção: não se prevê a revisão, a reescrita e a circulação do texto. Subentende-se, assim, que o aluno entregará seu texto para que o professor o corrija, ou seja, aponte os erros, e atribua uma nota, finalizando o processo de produção. Situação bem diferente quando a escrita é pensada como trabalho, em que o 
professor, ao ler o texto do aluno, age como leitor, como co-participante da produção do aluno, que gosta ou não do texto, que se emociona, aprende com ele, quer saber do que se trata, aponta caminhos para a reescrita, pois um texto nunca está pronto e acabado, mas deixa margens a novas versões (GERALDI, 1997).

É nítido, portanto, que os planos de aula vão de encontro às orientações expostas nos documentos oficiais e na bibliografia básica da própria disciplina de Estágio. A título de ilustração, retomamos o que diz Antunes - uma das autoras citadas no referencial da disciplina, a respeito da prática de produção textual. Segundo Antunes (2003), o professor não pode mais persistir numa prática de escrita meramente escolar, ou seja, sem leitor, sem finalidade, e também sem conteúdo, pois na sociedade atual há sempre uma razão para escrever. Isso deveria estar claramente explicitado nos planos de aula de modo a dar condições para que o aluno perceba a escrita como uma atividade dinâmica e significativa.

\section{Considerações finais}

Neste artigo, recuperamos as concepções de linguagem que orientam as práticas de ensino de língua materna na escola. Verificamos que essas diferentes concepções originam diferentes modos de se pensar e abordar a escrita em sala de aula. Assim, a concepção de linguagem como expressão do pensamento está relacionada às concepções de escrita com foco na língua e como dom; a concepção de linguagem como instrumento de comunicação atrela-se à concepção de escrita como consequência; finalmente, a concepção de escrita como forma de interação social remete à escrita como trabalho.

Ao discutirmos as propostas de produção de textos que constam nos planos de aula dos estagiários de um curso de Letras, constatamos que, embora os documentos oficiais de ensino (BRASIL, 1998) e as pesquisas em Linguística Aplicada (MENEGASSI, 2010) ressaltem a linguagem como forma de interação e a escrita como um trabalho, as atividades de produção de textos analisadas refletem as concepções de linguagem como expressão do pensamento e como instrumento de comunicação, as quais dão direções para se abordar a escrita em sala de aula como dom ou consequência. Consideramos isso um problema, visto que os estagiários certamente reproduzirão essa prática, como professores de Língua Portuguesa, proporcionando o ensino de redação (GERALDI, 1997), com fins unicamente escolares. 
Não se objetiva, neste artigo, discutir o porquê dessas concepções presentes nos planos de aula dos estagiários, pois, para isso, precisaríamos examinar o percurso acadêmico desses futuros professores; as teorias linguísticas apregoadas no decorrer do curso de Letras; o modo como essas teorias foram abordadas; as práticas de produção escrita realizadas em sala de aula da universidade; as discussões referentes à linguagem e ensino propiciadas nas disciplinas pedagógicas; as práticas de estágio já vivenciadas por esses acadêmicos. Entretanto, os planos de aula evidenciam que há necessidade de se proporcionar aos alunos de Letras reflexões mais aprofundadas a respeito das concepções de linguagem e de escrita, para que, futuramente, quando professores de Língua Portuguesa, eles possam criar situações didáticas em que a produção de textos esteja mais vinculada aos usos efetivos da linguagem.

\section{Referências}

ALMEIDA. J. Sobre redigir. Confluência - Boletim do Departamento de Lingüística. Assis: Faculdade de Ciências e Letras - UNESP, ano 4, no especial, 1995.

ANTUNES, I. Aula de Português: encontro e interação. São Paulo: Parábola Editorial, 2003.

BRANDÃO, H. H. N.; MICHELETTI, G. Teoria e prática da leitura. In: CHIAPPINI, L. (org.) Aprender e ensinar com textos didáticos e paradidáticos. Volume 2. São Paulo: Cortez, 1997.

BRASIL. Secretaria de Educação Fundamental. Parâmetros curriculares nacionais: terceiro e quarto ciclos do ensino fundamental: língua portuguesa. Brasília: MEC/ SEF, 1998.

BRITTO, L. P. L. A sombra do caos: ensino de língua x tradição gramatical. Campinas: ALB/ Mercado de Letras, 1997.

GERALDI, João Wanderley. Concepções de linguagem. In: GERALDI, João Wanderley. Organização: O texto em sala de aula: leitura e produção. Cascavel: ASSOEST, 1999. . Da redação à produção de textos. In: GERALDI, J. W. ; CITELLI, B. (org.).

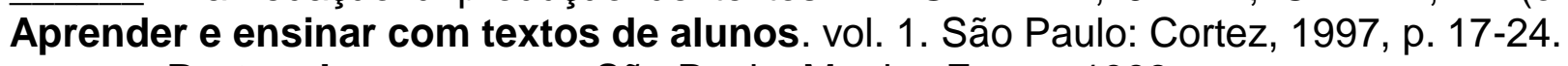
Portos de passagem. São Paulo: Martins Fontes,1993.

GOMES, S. Língua Portuguesa - 4aㅡ série. São Paulo/SP: IBEP, 2001.p.97-98.

GRILLO. M. Mlanejamento escolar. Disponível em http://portaldoprofessor.mec.gov.br/conteudoJornal.html?idConteudo=130. Acesso em 15/04/2012.

MENEGASSI, R. O processo de produção textual. In: SANTOS, A. R. dos; GRECO, E. A.; GUIMARÃES, T. B. (orgs.) A produção textual e o ensino. Maringá: Eduem, 2010. p.75101.

PARANÁ. Secretaria de Estado da Educação. Superintendência da Educação. Departamento de Ensino Fundamental.Orientações pedagógicas, língua portuguesa: sala de apoio à aprendizagem. Curitiba: SEED - PR, 2005.

PENKAL, L. L.; ANGELO, C. M. P. Linguagem e poder: reflexões sobre o ensino de gramática na escola. In: KRAUSE-LEMKE, C. et al. (org.). Cultura, linguagem e educação. Guarapuava: Unicentro, 2008, v. 1, p. 177-199. 
PERFEITO, A. M. Concepções de linguagem, teorias subjacentes e ensino de língua portuguesa. In: SANTOS, A. R. dos; RITTER, L. C. B. (org.). Concepções de linguagem e o ensino de língua portuguesa. UEM, 2005.

TRAVAGLIA, Luis Carlos. Gramática e interação: uma proposta para o ensino de gramática no $1^{\circ}$ e $2^{\circ}$ graus. 5.ed. São Paulo: Cortez, 2000. 